Original research article

\title{
Development of senior social services in the process of transformation and decentralisation and its present day forms in Slovakia
}

\author{
Lucia Ludvigh Cintulová *, Szilvia Buzalová \\ St. Elisabeth University of Health and Social Work in Bratislava, Bratislava, Slovak Republic
}

\begin{abstract}
The aim of this research study is to reflect historical development and analyse changes in the provision and funding of social services in Slovakia in the legislative framework - including a comparison of Act No. 195/1998 Coll. On social assistance and Act No. 448/2008 Coll. On social services. The qualitative research study analyses the impacts of the decentralization and transformation of social services on the basis of the practical experiences of the directors of non-public social services centres provided by church organisations. The total sample consisted of 41 managers working in social services. Data collection was completed at the end of 2019, and we used open coding, comparison, and categorization to reflect the development of social services. The results showed a rapid decrease in the number of low threshold social services and daily care centres for seniors. They also showed an increased number of elderly and vulnerable people over a 20 -year period. The law amendments made impact on the transformation and the modernisation of social services and the creation of new forms of institutional care services, including home care - which is much preferred due to the higher unemployment level of people over 50 who become home-care givers. The typology of clients has changed from "walkers" to seniors with IV.-V. degree of dependence on the long-term care. Home care has been replaced by residential care for the elderly. There is a huge need for the combination of social and health care in social care centres - including medical staff, care givers and social workers.
\end{abstract}

Keywords: Historical development of social services; Seniors; Transformation and decentralisation

\section{Introduction}

The transformation of social services in Slovakia has passed through a long-term process due to the hugely dominant status of the state in the social system - which did not allow democracy in the provision of public/non-public services. However, political, economic and global changes pushed the need of decentralisation, transformation and the modernisation of social work forward.

The transformation process reflected these key principles: decentralisation - moving competences to local level, and involving regional and community stakeholders in the provision of social services with an obligation to create community development plans. Demonopolization focuses on the improvement of the plurality of state and private subjects and gives space to non-profit organisations to provide various services for the poor, vulnerable and disabled people - based on the principles of democracy, an individual approach, and cooperation with the receivers of social services. Pluralisation of financial sources and forms of social services that make them effective, addressing the needs of individuals and social groups or communities without discrimination and marginalisation.
Modification of the object of social care when the position of an individual has changed from passive to active in the decision-making process, and problem-solving based on the principles of humanisation, individualism and holistic approach (Botek et al., 2014).

The year 2008 was a turning point for the development of social services. Reform of social services was based on the principles of transformation, decentralisation and individualism in the context of in the legislative framework of Act No. $448 / 2008$ On social services that declares new tasks to municipalities and regional stakeholders and the providers of social services. Receivers of the social services got "a real space for the enforceability of his right to choose a social service provider" (Repková and Brichtová, 2011, p. 10).

According to the previous reform, it was not possible to finance a non-public provider using public funds if the recipient of the social service chose it, despite being offered social services by a provider set up by the municipality or self-governing region, or if the client chose it without provision by the municipality or higher territorial region (Repková and Brichtová, 2011, p. 33).

In 2009, 69 non-public providers received state financial support for 714 clients. In the first half of 2010 there were

\footnotetext{
* Corresponding author: Lucia Ludvigh Cintulová, St. Elisabeth University of Health and Social Work in Bratislava, Námestie 1. mája 1, 81102 Bratislava, Slovak Republic; e-mail: luciacin83@gmail.com http://doi.org/10.32725/kont.2021.009 
190 non-public providers, offering senior services to almost 3,600 clients (Cangár, 2018).

Between 2010-2017, non-public social service providers mainly operated facilities with smaller capacities. On the one hand, this led to the individualisation of social services, on the other hand, these providers got into financial difficulties. Instead of focusing on service and social help (for which they were established) they had to focus only on their own existence and survival (Durana, 2017, p. 2). "The financing of social services needs to be adjusted so that there are motivations in the sector to innovate services and increase their quality."

The non-public providers of social services are faced with the problem of assertion within the local community. They have to fight to be included in the community plan of the municipality so that other providers of social work consider them competent and equal partners. (Milučký et al., 2017, p. 3).

The assessment process of dependence on social services is defined by Act No. 448/2008 Coll. On social services and Act No. 346/2018 Coll. includes the register of organisations in nonprofit sector including foundation, civic associations and social service providers.

Nowadays, social services face negative challenges due to the unstable political and economic situation, law changes and the Covid-19 pandemic. The fundamental problem is frequent changes in social laws not approaching equal conditions for all social service providers in Slovakia. Regional differences in public sources, social capital and human capital have a negative impact on the quality of long-term care of the elderly. The connection of health and social care is still missing. The development of social services is stagnating and the future financing of social services is unclear and unstable.

\section{Materials and methods}

The aim of the research is to analyse the development of social services that has been influenced by historical, social situation and political turbulences, which affected the quality of long-term care and social services. This research study's aim is to analyse the process of forming social services in Slovakia on the basis of the legislative framework, to transformation process of social services including practical experience of the non-public providers. Other research aims:

- Aim 1: to analyse the impact of decentralization, deinstitutionalisation and transformation on the current state of social services in Slovakia.

- Aim 2: to clarify the development and current state of social services provided by non-public providers.

- Aim 3: to identify changes in forms and types of social services reflected by amendments of social laws.

The qualitative part of the research was focused on analysing the process of transformation and historical development of social services and its impacts on a practice. We used structured interviews with managers in social service centres to analyse the important milestones in legislative framework and the political facts or social statistics. We used the "snowball" method to collect research data and the sample consisted of managers in social care centres. Radková (2006) defined qualitative research as a good method to get deeper in the research problems and analyse the current situation on the basis of open coding.

The statements of the sample were recorded and further analysed by open coding, categorized and compared mutually. The length of one interview was $45-60$ minutes. The content of the interviews consisted of questions that answered research questions in the following dimensions:

Dimension 1: Characteristics of social services providers

Q1: How would you characterise non-public providers and what are the typical characteristics compared to public providers?

Dimension 2: Historical development of social services

Q2: How have the forms of social services changed over the last 20 years?

Q3: How did the process of transformation, decentralisation and individualism have impact on the provision of social services up to today?

Dimension 3: Legislative changes and amendments to relevant laws linked to social services

Q4: Can you describe the developments and key milestones that influenced the providing and funding of social services on the basis of legislative framework?

Dimension 4: Funding of social services

Q5: How has the system of funding been changed compared to public social care providers?

\section{The sample}

The sample consisted of 41 managers working in social services. They were between $40-55$ years old with a practical experience of more than 10 years $(82.93 \%)$ in social care centres as non-public providers in the region Nitra (31.71\%), Trnava (17.07\%) and Bratislava (26.83\%). There is a higher number of women in the management of social services (61\%) compared to men (39\%) with a Master's degree (75.61\%) and $\mathrm{PhD}$ (24.39\%). $48.78 \%$ of them work in catholic church organisations, compared to $34.15 \%$ participants who work in evangelical church organisations and other non-public providers (17.07\%) - Table 1 .

\section{Table 1. Demographic characteristics of the sample}

\begin{tabular}{lrc}
\hline Demographic characteristics & $N$ & $\%$ \\
\hline Gender & & \\
$\quad$ Female & 25 & 60.97 \\
$\quad$ Male & 16 & 39.03 \\
Age & & \\
$\quad 40-45$ years old & 12 & 29.27 \\
$\quad 46-50$ years old & 20 & 48.78 \\
51-55 years old & 9 & 21.95 \\
\hline Practical experience & & \\
$\quad$ Less than 10 years & 7 & 17.07 \\
$\quad$ More than 10 years & 34 & 82.93 \\
\hline Education & & \\
$\quad$ Master's degree & 31 & 75.61 \\
$\quad$ PhD. & 10 & 24.39 \\
Workplace & & \\
$\quad$ Catholic church organisation & 20 & 48.78 \\
$\quad$ Evangelical church organisation & 14 & 34.15 \\
$\quad$ Other non-public providers & 7 & 17.07 \\
\hline Region of non-public social care & & \\
providers & & \\
$\quad$ Nitra & & \\
$\quad$ Trnava & & \\
$\quad$ Bratislava & 11 & 26.83 \\
\hline
\end{tabular}




\section{Results}

Qualitative research data were collected via interviews with the directors of social care centres in Slovakia. The data were collected at the end of 2019 (from September to December). We reported the answers of participants, recorded interviews, rewrote and then categorized and assigned individual codes to the obtained data by open coding, and categorized them by the frequency of repetition of the statement. Open coding allowed us to analyse the statements in more depth and thus gain an overview of the changes in the functioning, financing and forms of social services in practice. The results of the process of the transformation of social services, its main changes and the impacts are presented by these dimensions:

\section{Dimension 1: Characteristics of social services providers}

Research participants confirmed that there are significant differences between public and non-public social service providers, noting that there are several positive factors for the private providers where they work, including: less clients in the social care centres, a special type of social services for people with Alzheimer's disease or multiple sclerosis, the use of democratic principles in the management of social services based on equal decision-making, higher salaries and a motivational reward system. On the other hand, public and private social service providers face the same problems, such as: lack of qualified staff, fluctuation, insufficient funding, burnout and push and pull factors that have an impact on the implementation of innovations in the transformation and modernization of social services in connection with frequent amendments of social law - which makes for an unsustainable and unsecure environment (Table 2).

Table 2. Comparison of the providers of social services

\begin{tabular}{|c|c|c|}
\hline Categories - open coding & Non-public providers & Public providers \\
\hline Number of clients & $\begin{array}{l}\text { Lesser number of clients } \\
\text { At least } 15 \text { clients in senior care centre }\end{array}$ & $\begin{array}{l}\text { Higher number of clients } \\
\text { At least } 25 \text { clients in senior care centre }\end{array}$ \\
\hline Typology of social care receivers & $\begin{array}{l}\text { Specially oriented centres with lower level of social } \\
\text { dependence on social services }\end{array}$ & $\begin{array}{l}\text { Generally oriented centres with high level of social } \\
\text { dependence on social services }\end{array}$ \\
\hline Staff and salary in social services & Motivational benefits and a slightly higher salary & $\begin{array}{l}\text { Fixed salary component according to salary tables in } \\
\text { public administration }\end{array}$ \\
\hline Management of social services & Social-democratic model & Conservative and authoritative model \\
\hline Funding of social services & $\begin{array}{l}\text { Combination of church donation and state financial } \\
\text { sources with less money and individual payments }\end{array}$ & $\begin{array}{l}\text { Mainly from state financial sources, ESF and } \\
\text { individual payments }\end{array}$ \\
\hline Form of social services & Modernisation, transformation and decentralisation & Transformation, decentralisation and barrier breaking \\
\hline Supervision and external support & Regular supervision and external trainings for the staff & $\begin{array}{l}\text { Irregular supervision and lack of trainings and skills } \\
\text { development of the staff }\end{array}$ \\
\hline Philosophy & $\begin{array}{l}\text { Based on the church philosophy of helping and } \\
\text { showing love to others, empowering the vulnerable } \\
\text { and self-help }\end{array}$ & $\begin{array}{l}\text { Based on the philosophy of independent living, self- } \\
\text { help and crisis situations }\end{array}$ \\
\hline Effects on work & $\begin{array}{l}\text { Lack and loss of employers, burnout and the creation } \\
\text { of unmotivated environments }\end{array}$ & $\begin{array}{l}\text { Lack and loss of employers, burnout and the creation } \\
\text { of hostile environments, old staff members }\end{array}$ \\
\hline Modernisation of social services & $\begin{array}{l}\text { Push and pull factors lead to modernisations and need } \\
\text { of flexibility of social services due to social policy and } \\
\text { demographic forecasts }\end{array}$ & $\begin{array}{l}\text { There is a long-term process of implementation social } \\
\text { policy changes and implementation of modernisation } \\
\text { of social services in a real life/practice, often changes } \\
\text { in social policy }\end{array}$ \\
\hline
\end{tabular}

\section{Dimension 2: Historical development of social services} The research results have shown a great difference in provision of social services while comparing legislative Acts in 1998 and social Act in 2008 that are presented in Table 3. Research data identified the key aspects of the historical development of social services that are divided into 10 categories by open coding. The social care system is based more on institutional care - with a combination of home care services, but seniors dependant on long-term health and social care are usually moved from the home to senior care centres.

The typology of clients of social services has changed; collectivism has been replaced by autonomy in social services including individual skills-development plans. Compared to the past, the philosophy of social services is more focused on independent living, self-help and individualism; social rehabilitation is more often implemented outside of the social centre than in the past.
Due to the implementation of the current Act No. $448 / 2008$ On social services in Slovakia, it is possible to distinguish various types of social services for different social and age groups that are provided in several forms. Social services within the legislative framework had been provided differently at that time - in 1998, social services were centrally oriented compared to 2008 when social services became more oriented on the individual and the holistic approach. Within the development of social services, church organizations have developed other types of social services based on low-threshold care, especially in the Nitra region.

In the years 1998-2008, in the system of long-term care of seniors, institutional care was more prioritized compared to 2008 and onwards. Since 2008, ambulatory forms of senior care that together shape a comprehensive system of social services became more common. The amended Act no. 448/2008 On social services introduced assessment of citizens' depend- 
Table 3. Summary of historical development of social Acts

\begin{tabular}{|c|c|c|}
\hline Categories & Act No. $195 / 1998$ & Act No. $448 / 2008$ \\
\hline Social care facilities / Centres & $\begin{array}{l}\text { Institutional and residential care } \\
\text { Home care services } \\
\text { Only sheltered services }\end{array}$ & $\begin{array}{l}\text { Institutional care } \\
\text { Home care services } \\
\text { Sheltered services with low threshold and } \\
\text { independent living }\end{array}$ \\
\hline Social rehabilitation & Inside in the facility & Outside of the facility \\
\hline Philosophy & $\begin{array}{l}\text { Social re-integration } \\
\text { Collectivism in the provision of social services } \\
\text { Self-help services }\end{array}$ & $\begin{array}{l}\text { Independent living } \\
\text { Autonomy in decision-making and individualism } \\
\text { Self-help approach }\end{array}$ \\
\hline Providing social services & $\begin{array}{l}\text { No district selection in providing social services } \\
\text { No differences in the typology of the clients - } \\
\text { collectivism }\end{array}$ & $\begin{array}{l}\text { Residence address and the district } \\
\text { Specialized facilities and facilities for seniors with } \\
\text { specific diseases }\end{array}$ \\
\hline Basis of social services & Social care and nursing & Social and health care \\
\hline Clients' development & $\begin{array}{l}\text { Individual plans of self-help skills development in } \\
\text { hygiene, personal care and re-integration }\end{array}$ & $\begin{array}{l}\text { Individual plans of development of working skills, } \\
\text { independent living and social integration }\end{array}$ \\
\hline Number of clients & Huge number of clients in the social care facilities & Family approach in the provision of social care \\
\hline $\begin{array}{l}\text { Degree of dependence on social care } \\
\text { services }\end{array}$ & Not defined & Medium to high level \\
\hline Number of legislative amendments /Acts & 11 & 28 \\
\hline Providers of social services & Mostly public providers & Public and non-public providers \\
\hline
\end{tabular}

ency on social services, which caused an increased demand for social services. The providers of social services gained higher financial contributions from the state for clients/seniors with higher dependence on social services, which in practice led to artificial increase in the level of dependency on social services in citizens that need health and nursing care. The facilities are not able to cover this level of care for seniors, due to financial costs, low staff capacity and lack of senior placements.

Today, there are additional social services and early intervention that were not developed within the legislative framework Act No. 195/1998. This research study found that the forms of therapies and methods of social work with seniors has changed, and there are modern forms of therapies that have a positive impact on the well-being, quality of life and social development of seniors. The transformation of social services also brought new forms of therapies, and the modernisation of those therapies, which had already been implemented within services provided in social care centres. The most frequently used therapies are Snoezelen, Art-therapy, Basal simulation and others (Table 4).

\section{Dimension 3: Legislative changes linked to the development of social services}

This study compares the development of social services in 1998 compared to 2008. Decentralization and deinstitutionalisation made a major impact on the further development of social services and the identification of the types and forms of their provision. In 2008, the quality standards of social services and the registration of non-public social service providers became obligatory and nursing care for those who are dependent on social services became part of residential care. Act. No. $448 / 2008$ On social services defined the minimum standards for material and financial support, and imposes an obligation to provide supervision in social services to support the professional growth of employees and the prevention of burnout.

The historical factors, development and forms of social services on the basis of changes in social policy is presented in Table 5 below; the results have shown the impacts of social law amendments on the provision of social services and their development. This study identified the most significant changes that affected the performance of services in practice, and their

Table 4. Development of social services on the basis of changes in social Acts

\begin{tabular}{lll}
\hline Categories & Act No. 195/1998 & Act No. 448/2008 \\
\hline Ambulatory form & Less provided & New ambulatory forms \\
\hline Residential form & Prioritized & Preferred \\
\hline Street work & $\begin{array}{l}\text { Poor equality and no qualification criteria for street } \\
\text { work }\end{array}$ & Well-established and provided \\
\hline Additional social services & Central oriented & Case study oriented \\
\hline Early intervention & Not defined & New approach \\
\hline Degree of dependency on social services & Not defined & $\begin{array}{l}\text { Increased due to higher payments to social services } \\
\text { providers }\end{array}$ \\
\hline Forms of therapies & $\begin{array}{l}\text { Traditional forms of therapies - ergotherapy, social } \\
\text { rehabilitation }\end{array}$ & $\begin{array}{l}\text { Modern forms of therapies - e.g. basal stimulation, } \\
\text { Snoezelen, art therapy, animotherapy }\end{array}$ \\
\hline
\end{tabular}


Table 5. Development of social services in historical and legislative framework

\begin{tabular}{|c|c|c|}
\hline Categories & Act No. $195 / 1998$ On social assistance & Act No. $448 / 2008$ On social services \\
\hline $\begin{array}{l}\text { Starting point and } \\
\text { problem situation }\end{array}$ & $\begin{array}{l}\text { Social assistance is: } \\
\text { (a) social prevention } \\
\text { (b) problem solving and fulfilment of needs of citizens with } \\
\text { disabilities by financial compensation of social consequences } \\
\text { of disability }\end{array}$ & $\begin{array}{l}\text { Social services based on negative social situation, crisis } \\
\text { social situation on the personal level of dependence on social } \\
\text { service at different stages from I. to V. }\end{array}$ \\
\hline Forms of the care & $\begin{array}{l}\text { Institutional and outpatient care, day-care and residential care } \\
\text { Few non-public social service providers }\end{array}$ & $\begin{array}{l}\text { Institutional and outpatient care, day-care and residential } \\
\text { care } \\
\text { Non-public providers - social services boom, new forms and } \\
\text { values in social services } \\
\S 21 \text { - Social rehabilitation } \\
\S 22 \text { - Nursing care in the senior centres }\end{array}$ \\
\hline Social services tools & $\begin{array}{l}\text { Social counselling } \\
\text { Social and family children protection } \\
\text { Social services for specific groups } \\
\text { Social assistance benefits } \\
\text { Monetary contributions to compensate for the consequences } \\
\text { of disability } \\
\text { Financial support for disabled people as a part of law about } \\
\text { the social assistance } \\
\text { General standards for material and financial support } \\
\text { Supervision in social services not provided }\end{array}$ & $\begin{array}{l}\text { Social counselling } \\
\text { Social children protection } \\
\text { Wide range of social services and street services, home care } \\
\text { services } \\
\text { New social services in crisis and early intervention } \\
\text { New law to eliminate the consequences of disabilities - } \\
\text { financial support } \\
\text { Defined minimum standards for material and financial } \\
\text { support } \\
\text { Supervision in social services as obligatory }\end{array}$ \\
\hline
\end{tabular}

development was equally mentioned in the legislative changes and amendments, as well as the method of financing social services being different (Table 5).

\section{Dimension 4: Funding of social services}

The sample (managers of social services) explained several important aspects of funding social services that are supplemented by information from the political and legislative situation in the past.

The financial contribution was provided only if the service was indeed for a client-senior who was dependent on the service. The amount of the financial contribution was determined on the basis of the standard of operating costs per post for one financial year, causing many non-public providers and municipalities a legitimate feeling of insecurity and fear of the sustainability of social services. Since 2009, providers have been able to set up a social enterprise registered in the register of social enterprises, and "up to $70 \%$ of the funds obtained from the subject of activity can also be used for the development of social services" (Repková and Brichtová, 2011, p. 282). However, they had to use a third of their income to create new jobs or improve working conditions (Act No. 5/2004 Coll. on employment services).

The law allowed non-public providers to offer social services also for the purpose of making a profit. Public service providers could get higher financial support from the state com- pared to nonpublic providers due to strict regulation, unequal conditions of providing services for the vulnerable people and the limitation of number of clients.

Paradoxically, very few non-public providers have been used by the church (Table 6).

Long-term public care of seniors is predominantly financed by the municipalities through transferred state taxes, local taxes, state grants, and client co-payments, while municipalities, authorities of the self-governing regions, and, to a lesser extent, third sector organizations provide elderly care services with a different funding system (Szüdi et al., 2016). The financial and personal sustainability of social services is hard to follow due to the increased standards for quality of social care services, high maintenance costs, limited human capital, the high number of informal caregivers working abroad and lack of further financial plans.

\section{Discussion}

It is worth describing the chronology of the establishment process of social services, and to point out the important historical and relevant social events that influenced the transformation of social services in Slovakia. The year 1989 was characterized by complex political, economic and social changes. At the same time, the transformation of the economy had had

\section{Table 6. Funding of social services}

\begin{tabular}{ll} 
Open coding category & Description \\
\hline Decentralisation & Lack of financial transfers from VUC to lower representatives - municipality - mayors \\
\hline Financial system & No stability of funding system, contracting, co-payments \\
No equality & Differences in the amount of financial contribution for public and non-public providers \\
\hline Strategy of sustainability & Hard to implement in practice - no connection with the real needs and public possibilities or external sources \\
Community bridges & $\begin{array}{l}\text { Lack of community planning and its implementation in practice, lack of cooperation, communication and } \\
\text { prevention in public, private and nonprofit sector }\end{array}$ \\
Volunteering & Lack of long-term volunteering programmes in social services \\
\hline
\end{tabular}


an impact on changes in the social sphere. The period between 1989-1997 did not bring the expected changes and was limited to a partial reform that was not systemic and did not solve problems globally; focussing only on acute problems resulting from the economic crisis (Mitrík, 2018).

In 1998, the first social law was created, the priority was to support the integration of the citizens into society ( $\S 1$ of Act No. 195/1998 Coll. On social assistance). Social help was based on social prevention and solution of the material and social needs of citizens instead of empowerment and independent living or integration.

Act No. 195/1998 Coll. On social assistance contributed to the division of groups dependent on state assistance on the basis of the state of material and social need. The amount of the social assistance benefit was graded in three levels: "subsistence minimum", "living minimum" and "social minimum", depending on the reasons for asking for social help (Buchelová et al., 1998, pp. 167-169). Act No. 195/1998 Coll. On social assistance brought a number of basic philosophical changes compared to the previous period: (a) the transition from a philosophy of care to a philosophy of assistance, making maximum use of the individual efforts of the individual and his or her family to solve the situation; (b) social assistance based on a comprehensive assessment of the real needs; c) integrated medical and social care services and others (Repková and Brichtová, 2011). Demographic, political and social changes concerned a comprehensive process of transformation and decentralization. Looking at the present day changes in social policy and the process of transformation and decentralization, the number of social services facilities in 2001 before decentralization and after decentralization in 2004 has changed. These data are described in Table 7 below, from which it is clear that after decentralization, the number of state social centres increased and the number of non-public providers or founders under the jurisdiction of churches slightly increased.

Table 7. Effects of decentralisation of social services

\begin{tabular}{|c|c|c|}
\hline $\begin{array}{l}\text { Provider } \\
\text { Social care facilities }\end{array}$ & $\begin{array}{c}2001 \\
\text { BEFORE } \\
\text { decentralisation }\end{array}$ & $\begin{array}{c}2004 \\
\text { AFTER } \\
\text { decentralisation }\end{array}$ \\
\hline Church providers & 54 & 69 \\
\hline $\begin{array}{l}\text { Municipality public } \\
\text { administration }\end{array}$ & 25 & 142 \\
\hline $\begin{array}{l}\text { Other providers from private } \\
\text { sector }\end{array}$ & 43 & 119 \\
\hline State - specialized institutions & & 79 \\
\hline Public state sector & & 305 \\
\hline VUC - regional & 369 & \\
\hline VUC - local & 171 & \\
\hline
\end{tabular}

The Social Services Act No. 448/2008 Coll. declares the type of social service, the form of social service and the scope of social service provision is determined according to the negative social situation and the specific situation due to senior age, disability or chronic disease (Repková, 2016). The scope of services is established on the basis of biological aspects, and a socio-psychological and sociological approach that help to understand human being behaviour and needs (Rác and Ludvigh Cintulová, 2020).
On 28 November 2013, the National Council of the Slovak Republic approved Act No. 485/2013 Coll., focused on the improvement of the quality of social services, and their sustainability and accessibility. Social services were decentralized from state bodies to the self-governing competence of higher territorial units and municipalities. Social services currently represent a very wide area of helping clients in various life situations (Repková, 2017). The seniors do not need care in the field of nursing, food and accommodation, but prevention plays a key role in improving their quality of life to eliminate the consequences of the ageing of the population (Rottermund et al., 2015). Social services are one of the forms of social assistance to support people in an unfavourable life situation, and gives these people space to resolve this situation or achieve better life conditions. They are therefore an integral part of solving the problem (Budayová, 2019).

At the end of 2013, social services facilities had a total population of 43,845 . 30,002 of these were disabled people (68.4\%) and 24,910 were of retirement age (56.8\%). The total number of places in social service homes $(20,429)$ exceeded the total number of inhabitants $(19,401)$ in these facilities by 5.03\% (Šprocha, 2013).

Residential care is still a prioritized form of social services, together with the ambulatory form of social services and then street work is used to help vulnerable groups in their natural environment. There are about 280-300 social care centres with about 14.100 places for seniors. About 34.000 people over the age of 65 require domestic care, and about 8.000 caregivers are employed by the municipalities according to statistics in 2013. Based on the system of formal social care services for the elderly, Slovakia is typical for the rudimentary model: nursing and social institutional care are mostly preferred and the deinstitutionalized forms of services are less implemented in Slovak regions. Early intervention was implemented as a new form of services that was not implemented before 2008.

Compared to Lithuania, at the beginning of 2012 (according to the data from municipal and state institutions), about 7,600 people were employed in positions related to social work in municipal institutions, and about 9,900 people worked in positions related to social services in Lithuania (Ministry of Social Security and Labour in Vilnius, 2012). Under the Law on Social Services (19-01-2006, No. X-493), social services in Lithuania are provided by the social services providers: institutions of social services and social care providing general social services under an appropriate licence (Maciulskyte, 2014).

Poland is also looking at the key steps that need to be taken to modernise social care by moving from an institutional model towards a community-based model of care based on the strategy 'Long-term Senior Policy in Poland' for the years 2014-2020.

Although there is a trend towards care models with more integrated person-centred services, most countries continue to provide health and social care services for older people in senior centres rather than in an integrated way (European Social Network, 2017). In particular, Eurostat data shows that in 2030, people over 60 years old will constitute nearly $35-40 \%$ of the population all over Europe, in Poland it is $25 \%$ of Polish society (Sonik, 2013). The latest forecasts predict that the number of senior Europeans in the coming 50 years will double - from 87 million in 2010 to 148 million in 2060 (Eurostat, 2020). In Poland, there were 1,831 stationary social welfare institutions (108 more than in 2017), including 876 social welfare homes and 364 facilities providing 24-hour care to disabled, chronically ill or elderly people at the end of 
2018. Stationary social welfare institutions had 118.900 places (Statistical Institute in Poland, 2018).

The social services situation in Slovakia and the Czech Republic is similar. The long-term care services are usually provided by the regional stakeholders, NGOs and church organisations. The social services are not addressed in every region at the same level, so service users have to deal with two or three organisations in a system that is often opaque and lacks transparency.

A major problem is the current perception of the transformation of elderly care services, which is mainly understood as the transfer of services from institutions to community-based services. Thus, the community is seen solely as a replacement for the state. Responsibility is taken from the state to the municipal/regional level without the implementation of the necessary (financial) decentralization and organizational reform. This view is underpinned by recent domestic literature (Cangár, 2015; Repková, 2016; Repková and Brichtová, 2011; Šprocha, 2013). The transformation of social services is linked with the Deinstitutionalization strategy preferring community-type services on the home care basis, but legislative support is missing on how it can be implemented in practice, and what happens if it does not work for specific vulnerable groups.

In Hungary, the state is continually transferring residential care places to church ownership: "Over the past several years the maintenance of 3,087 residential care facilities has passed from the Directorate-General for Social Affairs and Child Protection to church control, affecting 25 locations in 2019." Compared to 2014, data from social statistics indicate that 2,240 places in residential care homes have been transferred to church control. According to data from June 2016, reported by Hungarian Directorate-General for Social Affairs and Child Protection, 16,853 people were waiting for a place in a nursing home, and at the beginning of 2019 this had risen to 24,824 (the real number could be around 35,000 , as it does not include the number of people on the long waiting lists). In 2016 there were 40 people waiting for every 100 occupied places in residential care homes, while 76 were waiting for every 100 occupied places in temporary care homes (Gyarmati, 2019).

Hungarian National statistical data in 2013 declared 39,000 people are working in specialist social care and 29,000 are working in basic social care. The number of people working in the social sector had increased to 198,600 by 2018. The number of care recipients per caregiver is 13 clients (HSCO, 2013).

The provision of a flexible service also requires the emergence of new forms of service providers or funders. Currently, $75 \%$ of long-term (residential and home) services are provid- ed by public providers, while the share of private nonprofit providers and private for-profit providers is $23 \%$ and $2 \%$, respectively (European Commission, 2012). These figures are relatively high, even in comparison to other Central European countries, and ranks closer to the values of Northern countries (Sweden, Finland), indicating an insufficient level of denationalization and privatization (Szüdi et al., 2016).

According to one study (Jacobs et al., 2009), the modernisation of social services needs to be linked with integration, independence, consistency, support for carers, meeting individuals' needs, and the workforce. On the other hand, community health and social services are related to chronic illnesses, mental well-being, income, gender and social status of the citizenship who are requiring social services (Cornes et al., 2011). There are three dimensions of sustainability: social (including the management of social services and its modernisation), ecological (social policy regarding the social, political and economic situation, equal conditions for public and non-public providers and market labour stability), and economic (including finance balance involving different financial sources from the state, public and non-profit sector), which need to be balanced constantly to keep a society and its social services sustainable and resilient (Kohl et al., 2020).

\section{Conclusions}

The research has shown the fundamental changes that have had a positive and negative impact on the current state of social services. We categorized these into 3 dimensions based on the historical development of social services, the legislative framework, reflecting changes in funding, social quality standards and provision of human resources, functionality and sustainability of social services, as well as amendments that have had an impact on the future planning, development and management of social services. The research results can be transferred at a micro-level to improve the process of providing social care services for individuals and communities of vulnerable people, and at a mezzo level by improving the standards of planning, organising and management of social services, and at a macro level to create space for designing social policy to make a positive and sustainable environment for the provision of social services in the future and to make them equal in the public and non-profit sector as well.

\section{Conflict of interests}

The authors have no conflict of interests to declare. 


\section{Vývoj sociálnych služieb pre seniorov v kontexte transformácie a decentralizácie a ich súčasné podoby na Slovensku}

\section{Súhrn}

Ciel'om výskumnej štúdie je reflektovat' historický vývoj a analyzovat' zmeny v poskytovaní a financovaní sociálnych služieb na Slovensku v rámci legislatívnych zmien porovnaním zákona č. 195/1998 Z. z., o sociálnej pomoci, a zákona č. 448/2008 Z. z., o sociálnych službách. Kvalitatívna výskumná štúdia analyzuje dopady decentralizácie a transformácie sociálnych služieb na základe praktických skúseností riaditel'ov neverejných centier sociálnych služieb poskytovaných cirkevnými organizáciami. Celkovú vzorku tvorilo 41 manažérov pôsobiacich v sociálnych službách. Zber údajov sa uskutočnil na konci roka 2019 a na analýzu vývoja sociálnych služieb sme použili otvorené kódovanie, porovnanie a kategorizáciu. Výsledky výskumu preukázali rýchly pokles počtu nízkoprahových sociálnych služieb, centier dennej starostlivosti o seniorov a zvýšený dopyt zranitel'ných osôb a starších l'udí za posledných 20 rokov. Novelizácia zákona a transformácia priniesli modernizáciu sociálnych služieb, nové formy služieb ústavnej starostlivosti vrátane domácej starostlivosti, ktorá je uprednostňovaná z dôvodu vyššej nezamestnanosti l'udí nad 50 rokov, ktorí sa stávajú poskytovatel'mi domácej opatrovatel'skej starostlivosti. Typológia klientov sa zmenila z „chodiacich“ seniorov na seniorov so IV.-V. stupeň odkázanosti na dlhodobú starostlivost́. Domáca starostlivost́ sa nahrádza reziduálnou starostlivostou o staršie osoby. Je vel'mi potrebné kombinovat' sociálnu a zdravotnú starostlivost́ v zariadeniach sociálnych služieb vrátane zdravotníckeho personálu, opatrovatel'ov a sociálnych pracovníkov.

Kl'účové slová: historický vývoj sociálnych služieb; seniori; transformácia a decentralizácia

\section{References}

1. Act No. 195/1998 Z. z., o sociálnej pomoci. In: Zbierka zákonov Slovenskej republiky.

2. Act No. 5/2004 Z. z., o službách zamestnanosti In: Zbierka zákonov Slovenskej republiky, čiastka 4/2004.

3. Act No. 448/2008 Z. z., o sociálnych službách a o zmene a doplnení zákona č. 455/1991 Zb., o živnostenskom podnikaní (živnostenský zákon), v znení neskorších predpisov. In: Zbierka zákonov Slovenskej republiky, čiastka 165/2008.

4. Act No. 346/2018 Z. z., o registri mimovládnych neziskových organizácií. Dôvodová správa k zákonu č. 346/2018 o registri mimovládnych neziskových organizácií. In: Zbierka zákonov Slovenskej republiky.

5. Botek O, Kállay A, Pavelek L, Slaná M (2014). Transformation of society, social policy and social work in Slovakia. ERIS Web Journal 5(1): 15.

6. Budayová Z (2019). Sociálne neprispôsobiví občania v intenciách sociálnej práce. Ružomberok: VERBUM vydavatel'stvo KU, $136 \mathrm{p}$.

7. Buchelová J, Sopira B, et al. (1998). Sociálna pomoc. Bratislava: Elita, $240 \mathrm{p}$.

8. Cangár M (2018). Prechod z inštitucionálnej na komunitnú starostlivost' v Slovenskej republike. Bratislava: SOCIA, 146 p.

9. Cornes M, Joly L, Manthorpe J, O'Halloran S, Smyth R (2011). Working Together to Address Multiple Exclusion Homelessness. Social Policy and Society 10(4): 513-522. DOI: 10.1017/ S1474746411000261.

10. Ďurana R (2017). Ako určit' cenu sociálnej služby? Bratislava: SOCIA, 43 p.

11. European Commission (2012). Long-term care for the elderly. Provisions and providers in 33 European countries. Luxembourg: Publications Office of the European Union.

12. European Social Network (2017) Investing in later life: A toolkit for social services providing care for older people. Brighton: European Social Network.

13. Eurostat (2020). Ageing Europe - statistics on population developments. [online] [cit. 2020-12-20]. Available from: https://ec.europa.eu/eurostat/statistics-explained/index.php/ Ageing_Europe_-_statistics_on_population_developments

14. Gyarmati A (2019). Ageing and Care for the Elderly in Hungary - General Survey and Problems. Budapest: Friedrich
Ebert Stiftung. [online] [cit. 2021-02-02]. Available from: https://library.fes.de/pdf-files/bueros/budapest/15482.pdf

15. HSCO (2013) Ötven év felettiek a munkaeröpiacon. [online] [cit. 2021-02-02]. Available from: http://www.ksh.hu/docs/ hun/xftp/idoszaki/pdf/otvenevfeletti

16. Jacobs S, Xie C, Reilly S, Hughes J, Challis D (2009) Modernising social care services for older people: Scoping the United Kingdom evidence base. Ageing and Society 29(4): 497-538. DOI: 10.1017/S0144686X08008301.

17. Kohl JL, van der Schoor MJ, Syré AM, Göhlich D (2020). Social sustainability in the development of service robots. Proceedings of the Design Society: DESIGN Conference, 1, 1949-1958. DOI: $10.1017 /$ dsd.2020.59.

18. Maciulskyte S (2014). The Code of Society Transformation in Social Work: Modelling the Construction of Lithuanian Social Work Professionalization. Acta Electronica Universitatis Lapponiensis: University of Lapland Printing Centre, Rovaniemi, $191 \mathrm{p}$.

19. Milučký J, Vallová J, Potásch P (2017). Judikatúra k správnemu poriadku a správnemu súdnemu poriadku. Bratislava: Eurokódex, s.r.o., 672 p.

20. Ministry of Social Security and Labour in Vilnius (2012). The Social Report 2011-2012. [online] [cit. 2021-02-03]. Available from: https://socmin.lrv.lt/uploads/socmin/documents/files/ pdf/711_socialreport2011-2012.pdf

21. Mitrík K (2018). Sociálne služby pre seniorov. Záverečná správa 2018. Prešov: Najvyšší kontrolný úrad SR. [online] [cit. 2021-02-02]. Available from: https://www.nku.gov.sk/ documents/10157/b8e2a0e2-4a1e-4d0a-8a1a-c1a3a31ce873

22. Rác R, Ludvigh Cintulová L (2020). The role of the social worker in working with the family in crisis in relation to the prevention of pathological behavior. International Review for Human and Natural Sciences 4: 85.

23. Radková L (2006). Základy štatistiky pre pomáhajuce profesie. Bratislava: SAP, $72 \mathrm{p}$

24. Repková K (2016). Kvalita v kontexte transformácie sociálnych služieb. Bratislava: Inštitút pre výskum práce a rodiny, 243 p.

25. Repková K (2017). Sociálne služby. Podpora zmysluplnej každodennosti v l'udsko-právnej perspektíve. Bratislava: Inštitút pre výskum práce a rodiny, $265 \mathrm{p}$.

26. Repková K, Brichtová L (2011). Sociálna ochrana starších osôb a osôb so zdravotným postihnutím - aktuálny vývoj. Bratislava: EPOS, 112 p. 
27. Rottermund J, Sauliez E, Knapík A (2015). Prevention of falls in the elderly with the use of preventive algorithm, Hygiena Public Health 50(1).

28. Sonik B (2013). Long-term Senior Policy in Poland for the years 2014-2020 in outline. Poland: Ministerstwo Pracy i Polityki Spolecznej.

29. Statistical Institute in Poland (2018). The situation of older people in Poland in 2018. Warszawa, Białystok.
30. Šprocha B (2013). Úmrtnost' a starnutie obyvatel'stva Slovenska. Prognóza budúceho vývoja v kontexte starobného dôchodkového systému. Prognostické práce 5(2). Prognostický ústav SAV.

31. Szüdi G, Kováčová J, Konečný S (2016). Transformation of Social Care Services for the Elderly in Slovakia. J Soc Serv Res 42: 199-217. DOI: 10.1080/01488376.2015.1129016. 